\title{
Stability and instability processes in the calli of Fagopyrum tataricum that have different morphogenic potentials
}

\author{
Alexander Betekhtin ${ }^{1}$ (D) Artur Pinski ${ }^{1} \cdot$ Anna Milewska-Hendel $^{2} \cdot$ Ewa Kurczynska $^{2} \cdot$ Robert Hasterok $^{1}$
}

Received: 9 August 2018 / Accepted: 7 February 2019 / Published online: 14 February 2019

(c) The Author(s) 2019

\begin{abstract}
The morphogenic callus (MC) of Fagopyrum tataricum contains a large amount of flavonoids, especially rutin, and exhibits a high level of antioxidant activity. A non-morphogenic callus (NC) may appear on the surface of the MC after two to three years of cultivation and is then subjected to a consistently high level of oxidative stress. The elucidation of the molecular background of this instability is essential for gaining a better understanding of the somaclonal variation mechanisms in tissue cultures that have different morphogenic potentials. Thus, in this study we show that continuous oxidative stress in a $\mathrm{NC}$ might be connected with a rapid senescence process and as a result, in the upregulation of the genes that are connected with the telomere complexity, ethylene biosynthesis and the expression of DNA methyltransferases. Moreover, we analysed the presence of the hydroxyproline-rich glycoproteins in the calli and demonstrated the differences between the MC and NC. The LM2 antibody can be useful as a marker of the cells in the MC that are embryogenically determined, while the MAC207 antibody seems to be a positive marker of a MC as its signal was absent in the NC. This study also provides the first report on the effect of trichostatin A on the DNA methyltransferases and demethylases in a MC.
\end{abstract}

\section{Key message}

LM2 can be used as a marker of the embryogenically determined cells. Overproduction of ethylene is present in the NC.

Keywords Fagopyrum tataricum $\cdot$ Calli $\cdot$ Morphogenic potential $\cdot$ Hydroxyproline-rich glycoproteins $\cdot$ Ethylene $\cdot$ The maintenance of telomere $\cdot$ DNA methyltransferases $\cdot$ Trichostatin A

\section{Introduction}

Buckwheat (Fagopyrum) are dicotyledonous plants of the Polygonaceae family. The genus consists of 26 annual and perennial species that primarily occur in the highlands of Eurasia. The two species that are the most cultivated are common buckwheat (Fagopyrum esculentum Moench) and Tartary buckwheat (Fagopyrum tataricum Gaertn) (Zhou

Communicated by Fredy Altpeter.

Alexander Betekhtin

alexander.betekhtin@us.edu.pl

1 Department of Plant Anatomy and Cytology, Faculty of Biology and Environmental Protection, University of Silesia in Katowice, Katowice, Poland

2 Department of Cell Biology, Faculty of Biology and Environmental Protection, University of Silesia in Katowice, Katowice, Poland
2018). F. tataricum contains a large amount of flavonoids, especially rutin, which due to its antioxidant activity, is well known for its beneficial medicinal effect in the treatment of the fragility of blood vessels and hypertension (Kreft 2016). Compared to F. esculentum, F. tataricum contains more phenolic compounds in every part of the plant as well as at different growth stages (Gupta et al. 2011). The seeds of $F$. tataricum contain higher amounts of rutin, i.e. $0.8-1.7 \%$ dry weight (d.w.), compared to the $0.01 \%$ d.w. in F. esculentum (Fabjan et al. 2003). The quantity and quality of protein in buckwheat is higher than in wheat, rice, maize and sorghum (Fabian and Ju 2011; Khan and Shewry 2009).

Recently, we demonstrated that the morphogenic callus (MC) of $F$. tataricum can retain nuclear genome stability during as many as ten years of its cultivation (Betekhtin et al. 2017). The appearance of a non-morphogenic callus (NC) on the surface of an MC seems to be connected with the endoreduplication cycles. As was demonstrated earlier, an MC consists of proembryogenic cell complexes (PECCs) and a 'soft' 
callus. During the cyclical callus development, the mature PECCs disintegrate, thereby giving rise to young PECCs and 'soft' callus cells. The NCs, which are formed exclusively from the parenchymous type cells of a callus, differ from the MCs due to their friable structure, high growth rate and complete loss of the capacity for morphogenesis (Betekhtin et al. 2017; Rumyantseva et al. 2003, 2004). The NC is a good example of the total instability and fast senescence in a plant tissue culture. The tissue culture research demonstrated that the MC of $F$. tataricum contains a large amount of phenolics as well as having a high antioxidant activity compared to the NC (Akulov et al. 2018). Moreover, the same authors highlighted the use of an F. tataricum tissue culture to study the metabolism of phenolic compounds as well as their being a promising alternative source of rutin and other biologically active phenolic compounds. A better understanding of the basis of any tissue culture-induced genetic variation should be helpful in developing more stable cell culture systems.

The primary cell wall plays an important role in regulating the morphogenetic processes (Knox 1992) and its chemical composition is crucial for establishing and/or maintaining the cellular differentiation status of cells (Corral-Martinez et al. 2016; Ikeuchi et al. 2013; Potocka et al. 2018). The main cell wall polysaccharides are pectins, and hydroxyproline-rich glycoproteins (HRGPs, arabinogalactan proteins (AGPs) and extensins), which all participate, though to a different extent, in cell expansion, adhesion and as regulatory molecules, and therefore, they are key determinants of the physical properties of the cell wall (Willats et al. 2001). It is well established that somatic embryogenesis (SE) is accompanied by modifications of the structure and molecular composition of the cell wall as well as specific gene expression (Kikuchi et al. 1995; Smertenko and Bozhkov 2014; Verdeil et al. 2001). The importance of HRGPs was shown for the embryogenic and non-embryogenic callus of sugarcane (Suprasanna et al. 2004). The authors demonstrated the HRGPs expression at all of the stages of callus development except the non-embryogenic one. Analysis of HRGPs during banana cultures also suggests that they play an important role in the regeneration process during SE (Pan et al. 2011). The correlation of changes between different HRGPs and reactive oxygen species is well documented (Cosi et al. 2007). HRGPs play a defensive role in host-pathogen interactions as well as changes in their presence under diverse biotic and abiotic factors (Basavaraju et al. 2009; Mareri et al. 2018). Despite the large number of reports about changes in the chemical composition of cell walls and changes in gene expression during SE, such analyses are still very limited for $F$. tataricum calli.

The aim of this study was to perform a complex analysis of the stability/instability in calli of F. tataricum that had different morphogenic potentials. We used immunolocalisation techniques against selected cell wall epitopes to compare whether they can be markers that are diagnostic for the MC and NC. Moreover, because of differences in the growth rate (very fast senescence in the $\mathrm{NC}$, we hypothesised that the ethylene biosynthesis genes are overexpressed in F. tataricum NC), genome stability/instability and, most importantly, in their morphogenic potential. Therefore, RT-qPCR was used to assess the expression of the genes that are connected with ethylene biosynthesis, telomere function and DNA methyltransferases/demethylases in relation to the different callus types. Trichostatin A (TSA) was used to demonstrate the affect of histone deacetylase (HDAC) inhibition on the DNA methyltransferases/demethylases.

\section{Materials and methods}

The lines of calli from immature embryos of $F$. tataricum were obtained in the Department of Plant Anatomy and Cytology, University of Silesia in Katowice, Poland. Both the $\mathrm{MC}$ and $\mathrm{NC}$ were cultivated in an incubator at $25^{\circ} \mathrm{C} \pm 1$ on an RX medium according to Betekhtin et al. (2017) with some minor modifications that are connected with the application of a ready-to-use B5 medium that includes vitamins (Duchefa, Haarlem, The Netherlands) for callus cultivation rather than a homemade medium.

\section{Histological and immunostaining procedures}

The MC and $\mathrm{NC}$ were fixed in a mixture of $4 \%$ paraformaldehyde and $1 \%$ glutaraldehyde in phosphate buffered saline (PBS, pH 7.2) overnight at $4{ }^{\circ} \mathrm{C}$. Next, the samples were washed three times in PBS for 15 min each, followed by a dehydration series in increasing ethanol concentrations and then gradually embedded in London Resin (LR White resin, St. Louis, USA). The samples were then cut into $1.5 \mu \mathrm{m}$ thick cross sections using an EM UC6 ultramicrotome (Leica Biosystems, Wetzlar, Germany) and the sections were placed on glass slides that had been coated with poly-L-lysine. For the general histology, the slides were stained with $0.05 \%$ (aqueous solution) Toluidine Blue O (Sigma-Aldrich, St. Louis, MO, USA) for $5 \mathrm{~min}$. For the immunocytochemical analyses, the sections were treated with a blocking buffer ( $2 \%$ foetal calf serum and $2 \%$ bovine serum albumin in PBS) for $30 \mathrm{~min}$ at room temperature (RT). Next, the samples were incubated with primary monoclonal antibodies (Plant Probes, Leeds, UK) that had been diluted 1:20 in a blocking reagent at $4{ }^{\circ} \mathrm{C}$ overnight. The sections were then washed in the blocking buffer three times and incubated with the secondary antibody, labelled with AlexaFluor 488 goat anti-rat IgG (Jackson ImmunoResearch Laboratories, Cambridgeshire, UK) and diluted 1:100 in the blocking buffer for $2 \mathrm{~h}$ at RT. The antibodies that were used are listed in Table 1. Next, the samples were washed in the blocking buffer followed by 
Table 1 The antibodies that were used for the immunocytochemistry with the relevant references

\begin{tabular}{|c|c|c|}
\hline Antibodies & Epitopes & References \\
\hline & Hydroxyproline-rich glycoproteins (HRGPs) & \\
\hline JIM8 & Arabinogalactan, AGP glycan & Pennell et al. (1991) \\
\hline JIM13 & $\begin{array}{l}\text { Arabinogalactan, arabinogalactan protein, } \beta \text {-D-GlcpA- }(1 \rightarrow 3)-\alpha- \\
\text { D-GalpA- }(1 \rightarrow 2) \text {-L-RhA }\end{array}$ & Knox et al. (1991), Yates and Knox (1994) and Yates et al. (1996) \\
\hline LM1 & Extensin, HRGP, the LM1 epitope most likely includes extensin & Smallwood et al. (1995) \\
\hline LM2 & $\begin{array}{l}\text { Arabinogalactan protein, recognises a carbohydrate epitope } \\
\text { containing } \beta \text {-linked glucuronic acid }\end{array}$ & Smallwood et al. (1996) and Yates et al. (1996) \\
\hline MAC207 & Arabinogalactan protein, (beta)GlcA $1 \rightarrow 3$ (alpha)GalA $1 \rightarrow 2$ Rha & $\begin{array}{l}\text { Bradley et al. (1988), Pattathil et al. (2010), Pennell et al. (1989) } \\
\text { and Yates et al. (1996) }\end{array}$ \\
\hline
\end{tabular}

staining with $0.01 \%(\mathrm{w} / \mathrm{v})$ fluorescent brightener 28 (FB28) (Sigma-Aldrich, St. Louis, MO, USA) in PBS, which was used to visualise cell walls due to its affinity to cellulose. Subsequently, the samples were rinsed in PBS and distilled water and dried sections were mounted on the slides with Fluoromount (Sigma-Aldrich, St. Louis, MO, USA). As a negative control, the primary antibody was omitted and the blocking buffer was applied along with all of the other steps of the procedure. All of the observations were made and the photographs were taken using an AxioImager Z2 epifluorescence microscope equipped with an AxioCam Mrm monochromatic camera (Zeiss, Oberkochen, Germany) that were equipped with narrow-band filters for AlexaFluor 488 and DAPI.

\section{Real time PCR}

A NucleoSpin ${ }^{\circledR}$ RNA Plant (Macherey-Nagel, Düren, Germany) was used to isolate the total RNA from both types of calli. The RNA was isolated on the 11 th day of cultivation when it was accompanied by the appearance of PECCs on the surface of the MC along with the high mitotic activity of the NC (Rumyantseva et al. 2004). TSA (Sigma-Aldrich, St. Louis, MO, USA) was used in the RX medium at concentrations of 2.5 and $5 \mu \mathrm{M}$. The concentration and quality of the isolated RNA was assessed using an ND-1000 NanoDrop spectrophotometer (Thermo Scientific, Waltham, MA, USA). First-strand cDNA was produced using a Maxima H Minus First Strand cDNA Synthesis Kit with dsDNase (Thermo Scientific, Waltham, MA, USA). The product of the reverse transcription was diluted with water at a $4: 1$ ratio and $2 \mu \mathrm{L}$ of this solution and was used for the Real Time RT-qPCR reactions using a LightCycler® 480 SYBR Green I Master in a LightCycler® 480 Real-Time PCR System (Roche, Mannheim, Germany). The primers that were relevant to the genes that were studied are listed in Table 2. The genomic sequence of $F$. tataricum cv. Pinku1 was downloaded from http://www.mbkbase.org/ Pinku1/ (online access 4 February 2018) and loaded into Geneious 11.1.2 software (http://www.geneious.com, Kearse et al. 2012). The genes of interest were found using a keyword search in the Buckwheat Genome DataBase (BGDB), which contains the draft genome sequence of $F$. esculentum Moench (http://buckwheat.kazusa.or.jp/index.html, online access 4 February 2018, Yasui et al. 2016). The identity of the targeted genes was additionally confirmed through BLAST searches using protein sequences as a query with respect to their similarities to Arabidopsis thaliana (Arabidopsis). The coding DNA sequences from the database were used as the query to search for the homologous genes in the $F$. tataricum cv. Pinku 1 genome using a BLAST search in Geneious. The alignments of the gene sequences from $F$. tataricum cv. Pinku1 and F. esculentum Moench were performed in Geneious using the Needleman-Wunsch algorithm. The gene-specific primers for the RT-qPCR analysis were designed from the identical sites in the genes of both species using PrimerQuest Tool software (https://eu.idtdn a.com/PrimerQuest/Home/Index).

The amplification efficiency of each gene was checked according to Taylor et al. (2010). The stability of the actin expression in the calli was checked using the BestKeeper Excel-based tool (Pfaffl et al. 2004). The relative changes in gene expression were calculated using the $2^{-\Delta \Delta C_{t}}$ method (Livak and Schmittgen 2001) and were normalised to the expression level of the actin. The calculations and statistical analysis were performed in the $\mathrm{R}$ (v 3.4.3) package pcr and the Student's t-test was used for the statistical analysis.

\section{Results}

\section{HRGPs in the MC and NC}

To test whether the selected HRGP epitopes were different between the types of calli that were studied, immunocytochemical analyses were performed using specific monoclonal antibodies: JIM8, JIM13, LM1, LM2 and MAC207 (Table 1). The representative histological character of the calli and cell features that were subjected to the immunocytochemical analyses are presented in Fig. 1a, e, i. The 
Table 2 Oligonucleotide primers used for RT-qPCR reaction with the relevant description of the genes

\begin{tabular}{|c|c|c|}
\hline Genes & Description of the genes & Primer sequence $\left(5^{\prime}-3^{\prime}\right)$ \\
\hline FtPinG0002124000.01 & Actin & $\begin{array}{l}\text { pF-GGAAGTATAGCGTCTGGATTG } \\
\text { pR-CTGGACCGGATTCATCATAC }\end{array}$ \\
\hline FtPinG0009372500.01 & Ethylene response factor 1 (ERF1) & $\begin{array}{l}\text { pF-AGAGTTAAGGAGGAAGAGGAG } \\
\text { pR-ACGTGTCGAATCTCGTATCT }\end{array}$ \\
\hline FtPinG0004556400.01 & 1-Amino-cyclopropane-1-carboxylate synthase 6 (ACS6) & $\begin{array}{l}\text { pF-GGCCATGGTGAAGAATCTG } \\
\text { pR-GCAAGACCCATCTGGATAAC }\end{array}$ \\
\hline FtPinG0004154200.01 & 1-Amino-cyclopropane-1-carboxylate synthase 2 (ACS2) & $\begin{array}{l}\text { pF-GATCCACCGGAGCTAATGA } \\
\text { pR-GCGGTCAAATGCAGGATAA }\end{array}$ \\
\hline FtPinG0008351200.01 & Aminocyclopropanecarboxylate oxidase 1 (ACO1) & $\begin{array}{l}\text { pF-CGGGACTTGAGTTCTACAAA } \\
\text { pR-CTCAGCACTTCCAGTTGAT }\end{array}$ \\
\hline FtPinG0000974100.01 & Telomerase activating protein Est1 (EST1) & $\begin{array}{l}\text { pF-GCTGCACCATTACAAGAGA } \\
\text { pR-CACTTCCTCTCTCACCATTAG }\end{array}$ \\
\hline FtPinG0008479800.01 & Telomerase reverse transcriptase (TERT) & $\begin{array}{l}\text { pF-TCAGCATGGGATCTAGTCTTAC } \\
\text { pR-CTGGTATTTACCACAAGGAATGG }\end{array}$ \\
\hline FtPinG0009136200.01 & Protection of telomeres protein 1 (POT1) & $\begin{array}{l}\text { pF-CGTACCAGGTTTCTTCAAACT } \\
\text { pR-TGTTTGACACTGTACCAAGG }\end{array}$ \\
\hline FtPinG0008019600.01 & Protection of telomeres protein 2 (POT2) & $\begin{array}{l}\text { pF-CTGGTTTGTGGTATGGTATCT } \\
\text { pR-GCACATTAAAGTCACTTAGGC }\end{array}$ \\
\hline FtPinG0006631600.01 & DNA (cytosine-5)-methyltransferase (CMT3) & $\begin{array}{l}\text { pF-CCACTGATCCCAGATTATGC } \\
\text { pR-GGTTCAGCTCTCCCAATAAC }\end{array}$ \\
\hline FtPinG0009406600.01 & DNA methyltransferase (MET1) & $\begin{array}{l}\text { pF-GCTGAAGAGGAAATAGAAGAGG } \\
\text { pR-CTGGGTGGATATTGAAGGAAG }\end{array}$ \\
\hline FtPinG0006897400.01 & DNA methyltransferase (MET2) & $\begin{array}{l}\text { pF-GTTGAAGATGAGGCAGAAGAA } \\
\text { pR-TGAGAGGATACTGATGGAGAC }\end{array}$ \\
\hline FtPinG0009482900.01 & DNA glycosylase DEMETER (DME1) & $\begin{array}{l}\text { pF-CCACACCAGAACAAGACATC } \\
\text { pR-GGTGAACTCTTCAACATCCAG }\end{array}$ \\
\hline FtPinG0007109000.01 & DNA glycosylase DEMETER (DME2) & $\begin{array}{l}\text { pF-GGAAGCATTGATTTGGAATGG } \\
\text { pR-AAAGCCTAACACACTCTACAC }\end{array}$ \\
\hline FtPinG0003657700.01 & DNA glycosylase DEMETER (DME3) & $\begin{array}{l}\text { pF-CCACAGATTCAACAGTCCTC } \\
\text { pR-GGCCTATGCTTCTTTCTTCT }\end{array}$ \\
\hline FtPinG0007109000.01 & DNA glycosylase, repressor of transcriptional gene silencing (ROS1) & $\begin{array}{l}\text { pF-GAAGTAACGAGAGCCCTTTAG } \\
\text { pR-CCTGGGAGTTTGTGATGTT }\end{array}$ \\
\hline
\end{tabular}

MC consisted of PECCs that had phenolic-containing cells (Fig. 1a, arrows) and a 'soft' callus (Fig. 1a, asterisks; e) compared to the NC, which consisted of only parenchymoustype cells (Fig. 1i; due to the difficulty in separating the fluorescence signals that were present in the cell wall and plasma membrane using light microscopy, these two compartments are described together. The signals inside the cells were localised in the intracellular compartments).

The JIM8 epitope in the embryogenic cells of the MC calli was distributed in the cell walls and in the cytoplasm in a dotted manner (Fig. 1b-d). The presence and distribution of this epitope in the "soft" callus was similar to that described above (Fig. 1f-h). Compared to the MC, the epitope labelled with JIM8 antibody in the NC cells was abundantly present in the cytoplasm compartments, in the cell wall and in the newly formed cell walls in particular. This signal was uniformly distributed along the entire length of the walls (Fig. $1 \mathrm{j}-1,1$ arrows demonstrate the newly appearing cell walls). The main differences between the MC and NC calli rely on the amount of the AGP epitope that are recognised by the JIM8 and its cellular localisation, which indicated that the occurrence of this epitope in the NC callus cells was more abundant in both the cytoplasm and the wall. Although the JIM13 signal was present in the cytoplasm compartments in both calli, it was more abundantly present in the NC cells (Fig. 2). The distribution of this epitope was also observed in the cell walls in a dotted manner in the MC cells (Fig. 2b, c, e, f) and was uniformly stained in the NC cells (the reverse of the case of the JIM8 epitope).

Unlike the two previous epitopes, the LM1 epitope was present in the intercellular spaces and on the surface of the phenolic-containing cells (Fig. 3b, e, arrows) and embryogenic cells in the MC cells (Fig. 3a-f). In the NC, it was localised on the surface and in the intercellular spaces (Fig. 3g-1). In the MC, the LM2 antibody was localised in the intracellular compartments (Fig. $4 a-c$ ), and in some cases, it was probably also localised in the plasmalemma of the embryogenic and the "soft" callus cells but in very 

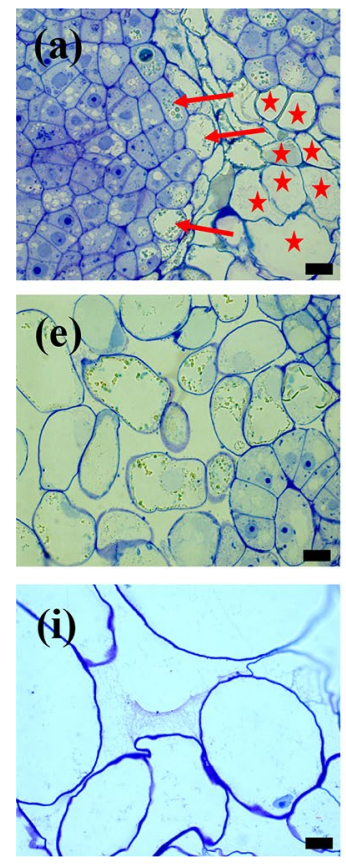
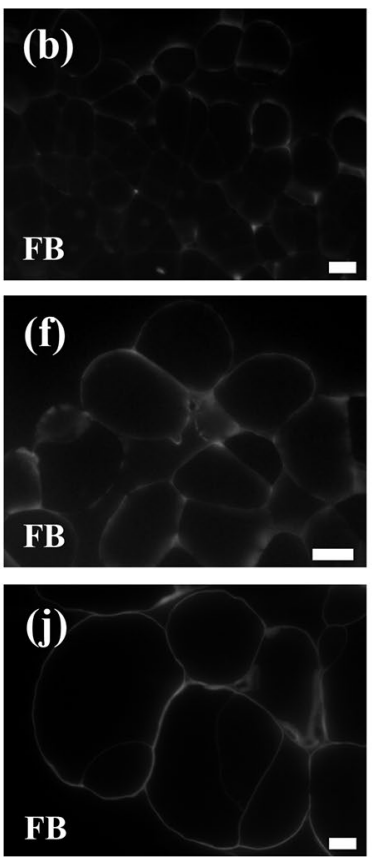
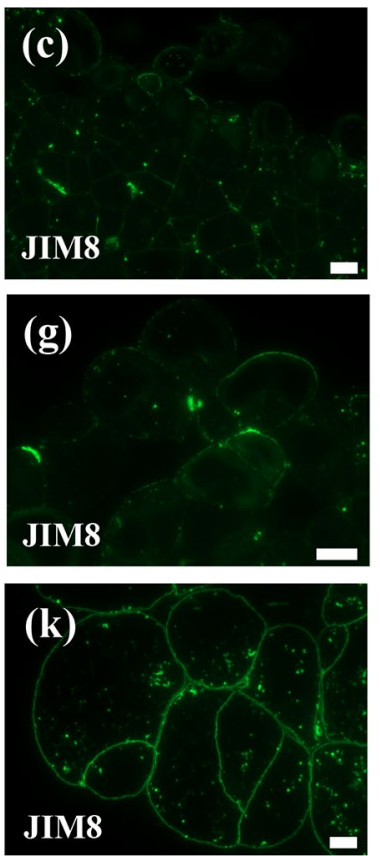
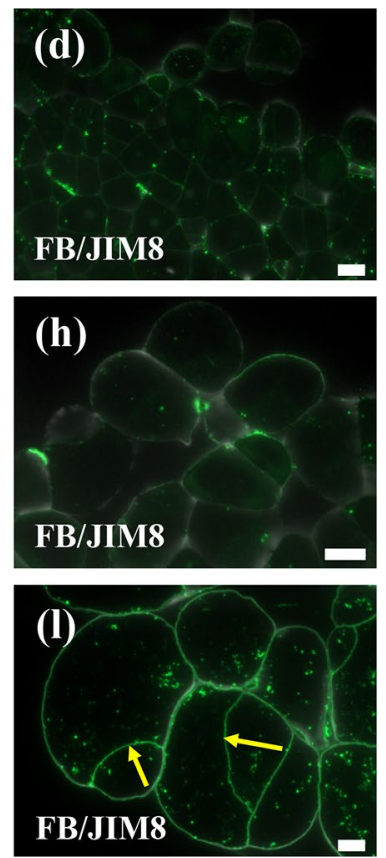

Fig. 1 Histological sections of the F. tataricum $\mathrm{MC}(\mathbf{a}, \mathbf{e})$ and in $\mathrm{NC}$ (i). Immunolocalisation of JIM8 in the MC (b-d, $\mathbf{f}-\mathbf{h})$ and $\mathrm{NC}(\mathbf{j}-\mathbf{l})$. $F B$ fluorescent brightener. a Arrows demonstrate the phenolic-containing cells, asterisks 'soft' callus cells. I Arrows demonstrate newly

low amounts (Fig. 4f). The signals of this antibody were absent or almost absent in the plasmalemma of the phenoliccontaining cells (Fig. 4b, e, asterisks). Compared to the MC, in the NC calli, LM2 was detected in the cell wall and in the intracellular compartments (Fig. $4 \mathrm{~g}-1$ ). The immunolocalisation of MAC207 demonstrated the presence of this epitope in the intercellular spaces of the "soft" callus cells (Fig. 5a-f) and in the intracellular compartments in some cells of the MC (Fig. 5a-c). The NC callus cells were completely negative for the MAC207 signals (Fig. $5 \mathrm{~g}-\mathrm{i}$ ).

\section{RT-qPCR of selected genes}

In order to characterise the differences that are present between the MC and NC at the molecular level, the genes that are connected with the biosynthesis of ethylene and with the metabolism of ethylene precursors as well as with the telomere length homeostasis and chromosome end protection were assessed (the descriptions of the genes are listed in Table 2). The similarities of the selected genes on the protein level to the proteins encoded by the genes from Arabidopsis are shown in Table 3. The expression of the actin gene was found to be stable in the buckwheat tissue culture material, thus it was used as the reference gene. Moreover, the amplification efficiency for each gene was determined to be close to $100 \%$, thereby permitting the calculations according to the $2^{-\Delta \Delta C_{t}}$ method (Livak and Schmittgen 2001). The appeared cell walls. The greenish background visible on some photomicrographs is due to the autofluorescence. Scale bars $10 \mu \mathrm{m}$. (Color figure online)

relative expression level of $A C S 2, A C S 6$ and $E R F 1$ were high in the NC. The ACS2 and ACS6 genes were 55- and 30-fold more expressed in the NC. The ERF1 demonstrated a five times higher expression in the NC (Fig. 6a). The expression level of ACOl was lower in the NC (Fig. 6a). The relative expression levels of TERT, EST1 and POT1 were higher in the NC (Fig. 6b). The ESTl was characterised by a 20 -fold time higher expression in the NC compared to the MC. The POT2 expression level was slightly higher in the MC than in the NC (Fig. 6b).

The expression levels of the DNA methyltransferases such as $M E T 1$ and MET2 differed to various degrees between the MC and NC, with the exception of CMT3, for which no statistically significant differences were observed (Fig. 6c). The highest level of expression was characteristic for METI and it was six times higher in the NC than in the MC. In contrast, the expression of MET2 was only slightly higher in the NC compared to the MC. The expression of all of the demethylases (DME1,DME2,DME3 and ROS1) that were analysed was consistently lower in the NC. In order to analyse the influence of the HDAC inhibition on the on the DNA methyltransferases and demethylases in the MC, we used two different concentrations of TSA $(2.5 \mu \mathrm{M}$ and $5 \mu \mathrm{M}$ ), which was added to the cultivation medium. The results demonstrated an increase in the expression level of all of the analysed methyltransferases and demethylases compared to the untreated MC and that the use of TSA at 

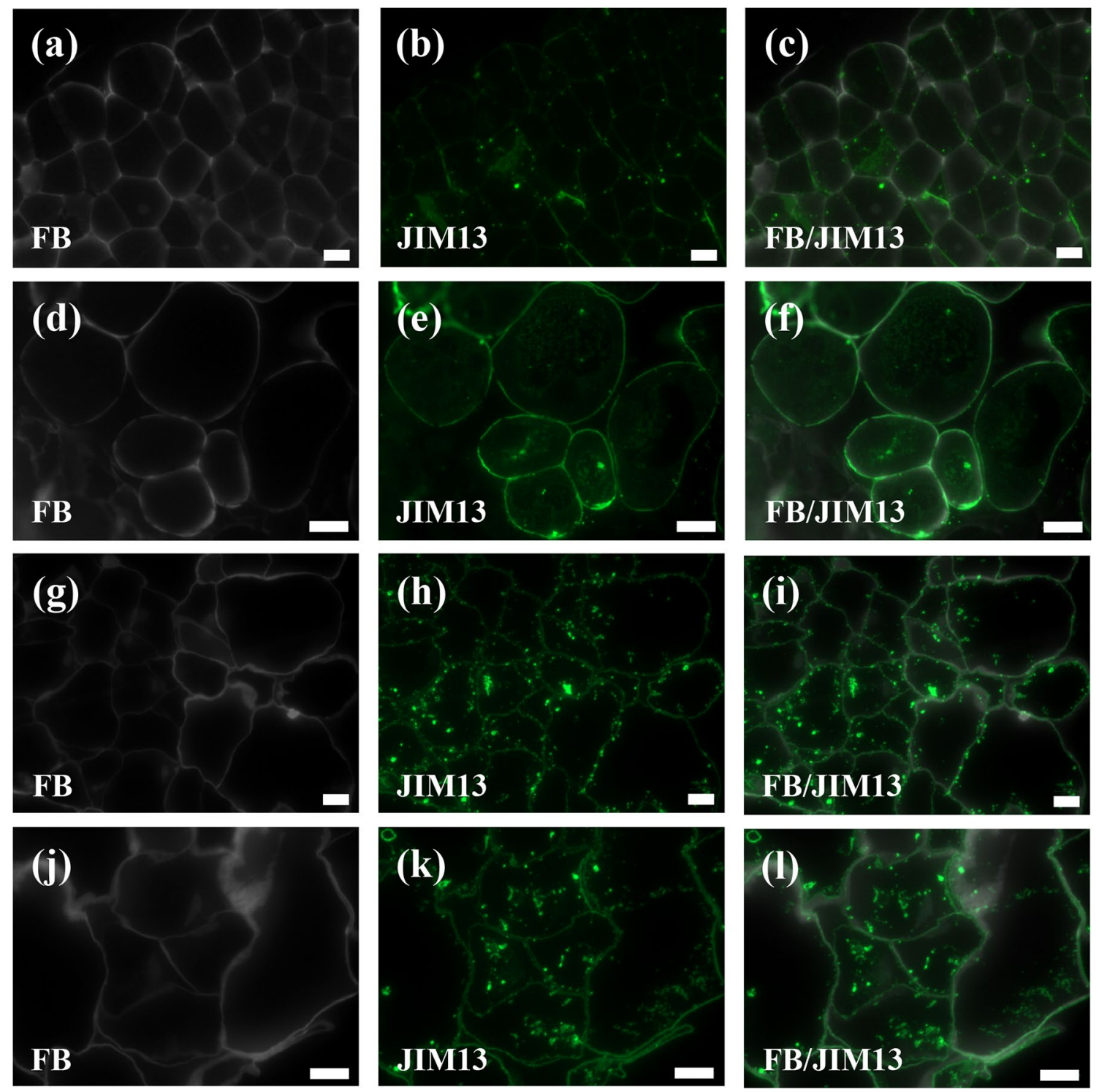

Fig. 2 Immunolocalisation of JIM13 in the F. tataricum MC (a-f) and NC (g-l). The greenish background visible on some photomicrographs is due to the autofluorescence. Scale bars $10 \mu \mathrm{m}$. (Color figure online)

a lower concentration resulted in a more prominent effect (Fig. 6d). However, the dynamics of the gene expression clearly decreased at a concentration of $5 \mu \mathrm{M}$.

\section{Discussion}

In our work, selected AGPs and extensins were investigated because of their well-known involvement in different developmental processes, including plant growth and development, plant defence, cell proliferation, cell expansion, cell differentiation, cell extension and SE (Pennell 1998; Smith 2001). AGPs are one of the extracellular matrix surface network components that are pivotal for the cell division and expansion, programmed cell death, SE and many other crucial aspects of the plant cell functions (Betekhtin et al. 2016; Chapman et al. 2000; Rumyantseva 2005; Samaj et al. 2008). The studies on F. tataricum suggested the presence of this matrix in the MC and its total absence in the NC (Rumyantseva et al. 2003). It was shown that the F. tataricum MC secreted much more extracellular polymers into the medium compared with the NC (Rumyantseva et al. 2004). A significant increase in the secretion of extracellular polymers was connected with the formation of the PECCs. However, these authors did not specify the AGPs or extensins that were secreted. The experiments that were performed in the present study demonstrated the presence of 'patchy' signals of LM1 on the surface of a PECC in both the MC and NC. 

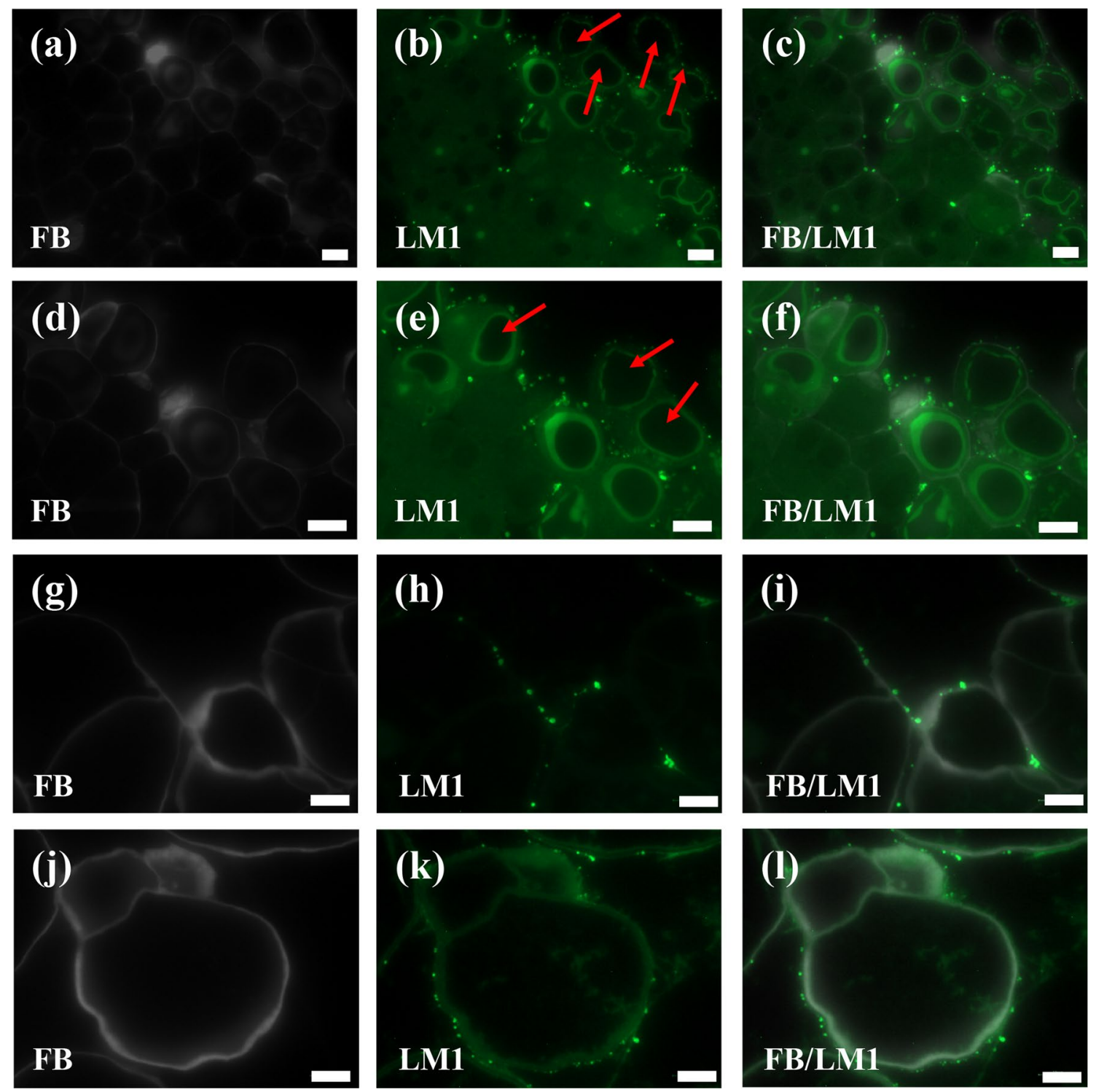

Fig. 3 Immunolocalisation of LM1 in the F. tataricum MC (a-f) and NC (g-l). The greenish background visible on some photomicrographs is due to the autofluorescence. $\mathbf{b}$ and $\mathbf{e}$ Arrows: the phenolic-containing cells. Scale bars $10 \mu \mathrm{m}$. (Color figure online)

Thus, this type of extensins may be crucial for some developmental processes in both types of the callus. MAC207 seems to be a marker of the MC of F. tataricum as it was only present in the intercellular spaces of the "soft" callus cells and in the intracellular compartments (very rarely in some cells) of the MC and was totally absent in the NC. The involvement of this epitope was analysed during in vitro cultures, including microsporogenesis (El-Tantawy et al. 2013; Showalter 2001), but most often during zygotic embryogenesis (Leszczuk and Szczuka 2018), thus a comparison of our studies with the literature data is difficult. Nevertheless, the prominent function of these AGPs seems to be the cell-cell interactions or cellular signalling during the formation of a new PECC. The possibility of mediating signal transduction at the cell wall-plasma membrane interface by AGPs was demonstrated earlier in several studies (Kohorn 2001, 2016; Showalter 2001).

For carrot, maize and Arabidopsis, it was shown that the embryogenic callus is marked by its presence in cell walls of the AGP epitopes that are recognised by the JIM8 antibody (Majewska-Sawka and Nothnagel 2000; Potocka et al. 2018). Other studies have shown that this epitope is necessary for somatic embryo formation (McCabe et al. 1997). In the AGPs in the embryogenic calli of $F$. tataricum that have been analysed to date, the presence of JIM4, LM2, JIM13 and JIM16 epitopes has been suggested (Rumyantseva 2005). In Arabidopsis explants, LM2 gave either no signal or a very weak signal in the cells that displayed typical embryogenic 

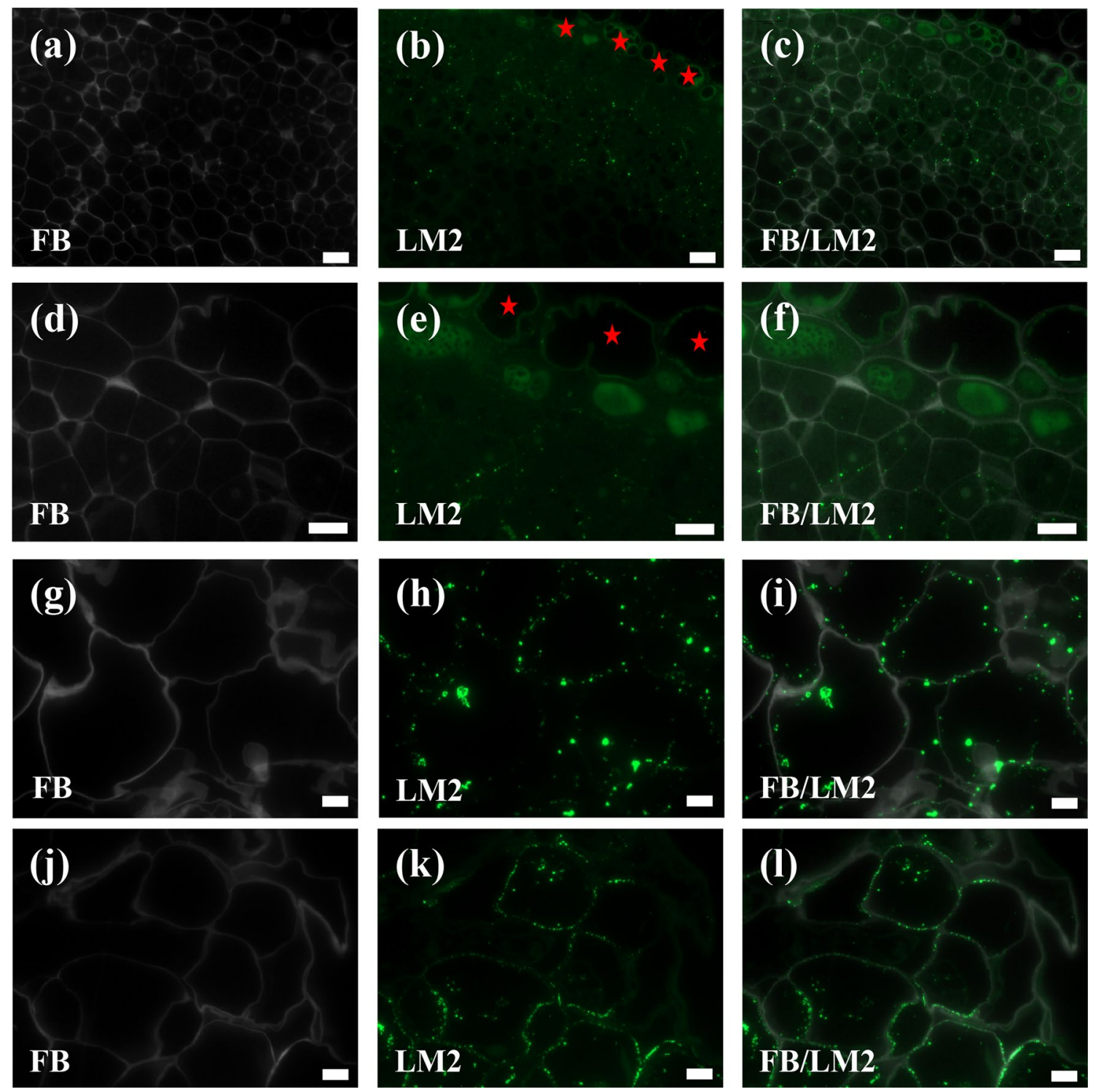

Fig. 4 Immunolocalisation of LM2 in the F. tataricum MC (a-f) and NC (g-l). Asterisks: the phenolic-containing cells. The greenish background visible on some photomicrographs is due to the autofluorescence. Scale bars $10 \mu \mathrm{m}(\mathbf{d}-\mathbf{l}), 20 \mu \mathrm{m}(\mathbf{a}-\mathbf{c})$. (Color figure online)

features, but in all of the neighbouring cells, its presence was abundant in different intracellular compartments (Potocka et al. 2018). A similar pattern of LM2 epitope distribution was reported for the highly embryogenic cell line of a hybrid fir (Abies alba x Abies cephalonica) in which the signals were weak in the cell walls of the embryogenic cells and much stronger in the cytoplasm compartments of the large vacuolated compartments of the cells that were not engaged in SE (Samaj et al. 2008). Thus, our results for F. tataricum are consistent with those that have been obtained for other species to date.

Interestingly, for both JIM8 and JIM13, we found a visible increase of the signal intensity in the NC. As was demonstrated in some earlier studies, the NC is under constant oxidative stress (Kamalova et al. 2009) and AGPs are known to be involved in the salt stress response (Lamport et al. 2006; Olmos et al. 2017). Thus, it is likely that during such stress conditions, they may act as a plasticiser to loosen the pectin network or as a cell wall stabiliser. Gong et al. (2012) demonstrated that the overexpression of GhAGP31, which encodes a nonclassical AGP in cotton, significantly improved the freezing tolerance of yeast cells and the cold tolerance of Arabidopsis seedlings.

All of the AGP epitopes that were analysed in the present study indicate the role of AGPs, as the key constituents of the cell wall that are involved in the diverse reactions of a 

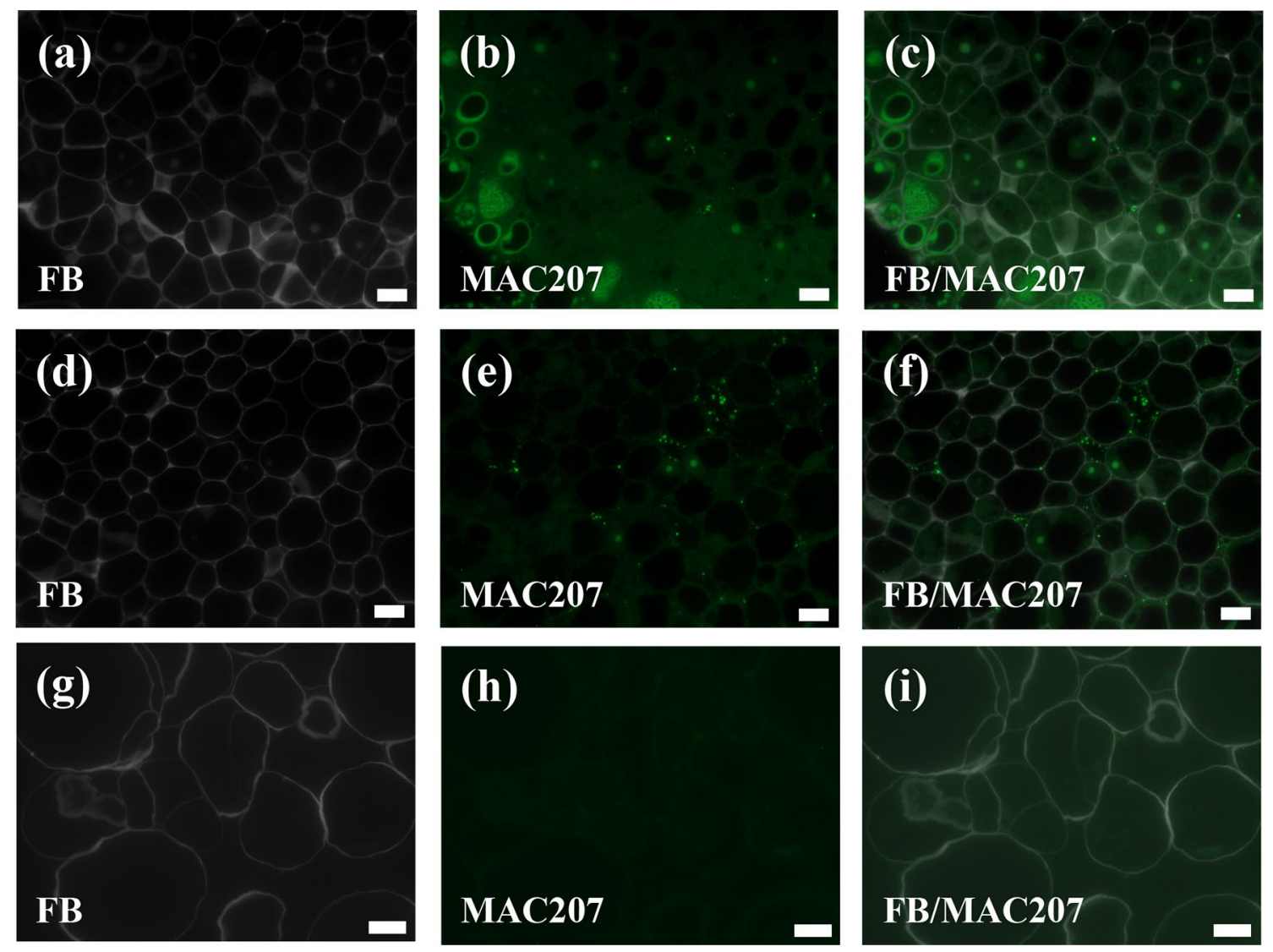

Fig. 5 Immunolocalisation of MAC207 in the F. tataricum MC (a-f) and NC (g-i). The greenish background visible on some photomicrographs is due to the autofluorescence. Scale bars $10 \mu \mathrm{m}$. (Color figure online)

cell. Observations of the distribution of AGPs in embryogenic tissue of winter oilseed rape suggested that AGPs may play a specific role in embryogenic competency or in determining the embryogenic cells fate (Namasivayam et al. 2010). The MAC207 and LM2-binding epitopes are involved in plant morphogenesis, which is suggested by the correlation between their presence and the embryogenic potential of the callus tissue (Wiśniewska and Majewska-Sawka 2008). Extensive studies have revealed that AGPs, including those that are recognised by the antibodies that were used in present work are specific markers of the cell identity and the direction of cell differentiation in in vitro cultures (Konieczny et al. 2007). AGPs that contain JIM13 and LM2 epitopes as well as pectins seem to be important for the formation and proper assembly of the wall and providing a network for the attachment of other cell wall components (Majewska-Sawka and Munster 2003). To summarise, AGPs and extensins are broadly distributed in tissue and callus cultures, and their function in various aspects of plant growth and development, including the participation of these wall components in the formation of the plant cell surface continuum, has been postulated (Borassi et al. 2016).
As we demonstrated in this study, the high level of oxidative stress in the $\mathrm{NC}$ is connected with a significant increase in the expression of the EST1 gene. EST1 is a multifunctional protein that plays a critical role in the maintenance of telomeres as well as in the stimulation of the telomerase activity in yeasts (Renfrew et al. 2014). Mutations in EST1 lead to telomere shortening (Lundblad and Szostak 1989). Moreover, the analysis of the expression of the F. tataricum protection of telomere genes, FtPotl and FtPot2, in the present study revealed a higher expression of FtPotl in the NC compared to the MC. We demonstrated that the upregulation of FtPotl is correlated with the upregulation of TERT in the NC. The downregulation of both of these genes was a characteristic feature of the MC. The buckwheat calli did not show any strong differences in the expression of FtPot 2 but the exact functions and binding properties of POT1 and POT2 are still under debate (Prochazkova Schrumpfova et al. 2016). The genome of Arabidopsis contains two POT1-like proteins, AtPOT1 and AtPOT2 (Shakirov et al. 2005). It was demonstrated that AtPOT1 appears to be an important positive regulator of telomere length, while AtPOT2 negatively regulates the telomerase activity and participates in protecting the chromosome ends. Shakirov et al. (2005) 
Table 3 The identity between F. tataricum and Arabidopsis genes on the protein level

\begin{tabular}{|c|c|c|c|c|c|c|c|}
\hline Genes & $\begin{array}{l}\text { Description of the } \\
\text { genes }\end{array}$ & $\begin{array}{l}\text { Amino } \\
\text { acids length } \\
\text { (aa) }\end{array}$ & Arabidopsis best hit & $\begin{array}{l}\text { Arabidopsis gene } \\
\text { description }\end{array}$ & $\begin{array}{l}\text { Amino acids } \\
\text { identity }(\%)\end{array}$ & $\begin{array}{l}\text { Query } \\
\text { cover } \\
(\%)\end{array}$ & E-values \\
\hline FtPinG0009372500.01 & $\begin{array}{l}\text { Ethylene response fac- } \\
\text { tor } 1(E R F 1)\end{array}$ & 218 & AT3G23240.1 & $\begin{array}{l}\text { Ethylene-responsive } \\
\text { transcription factor } \\
\text { IB }\end{array}$ & 52 & 99 & $8 \mathrm{E}-66$ \\
\hline FtPinG0004556400.01 & $\begin{array}{l}\text { 1-Amino-cyclopro- } \\
\text { pane-1-carboxylate } \\
\text { synthase } 6 \text { (ACSO) }\end{array}$ & 573 & AT4G11280.1 & $\begin{array}{l}\text { 1-Aminocyclopropane- } \\
\text { 1-carboxylate } \\
\text { synthase } 6\end{array}$ & 65 & 82 & 0.0 \\
\hline FtPinG0004154200.01 & $\begin{array}{l}\text { 1-Amino-cyclopro- } \\
\text { pane-1-carboxylate } \\
\text { synthase } 2 \text { (ACS2) }\end{array}$ & 491 & AT1G01480.1 & $\begin{array}{l}\text { 1-Aminocyclopropane- } \\
\text { 1-carboxylate } \\
\text { synthase } 2\end{array}$ & 63 & 97 & 0.0 \\
\hline FtPinG0008351200.01 & $\begin{array}{l}\text { Aminocyclopropane- } \\
\text { carboxylate oxidase } 1 \\
(\text { ACO1 })\end{array}$ & 308 & AT2G19590.1 & $\begin{array}{l}\text { 1-Aminocyclopropane- } \\
\text { 1-carboxylate } \\
\text { oxidase } 1\end{array}$ & 69 & 95 & $6 \mathrm{E}-156$ \\
\hline FtPinG0000974100.01 & $\begin{array}{c}\text { Telomerase activating } \\
\text { protein Est } 1 \text { (EST1) }\end{array}$ & 969 & AT5G19400.1 & $\begin{array}{l}\text { Telomerase activating } \\
\text { protein Est } 1\end{array}$ & 50 & 90 & 0.0 \\
\hline FtPinG0008479800.01 & $\begin{array}{l}\text { Telomerase reverse } \\
\text { transcriptase }(T E R T)\end{array}$ & 718 & AT5G16850.1 & $\begin{array}{l}\text { Telomerase reverse } \\
\text { transcriptase }\end{array}$ & 30 & 90 & $3 \mathrm{E}-71$ \\
\hline FtPinG0009136200.01 & $\begin{array}{l}\text { Protection of telomeres } \\
\text { protein } 1(P O T 1)\end{array}$ & 468 & AT2G05210.1 & $\begin{array}{l}\text { Protection of telom- } \\
\text { eres } 1\end{array}$ & 40 & 97 & $1 \mathrm{E}-96$ \\
\hline FtPinG0008019600.01 & $\begin{array}{l}\text { Protection of telomeres } \\
\text { protein } 2 \text { (POT2) }\end{array}$ & 467 & AT5G06310.1 & $\begin{array}{l}\text { Protection of telom- } \\
\text { eres } 2\end{array}$ & 37 & 97 & $1 \mathrm{E}-88$ \\
\hline FtPinG0006631600.01 & $\begin{array}{l}\text { DNA (cytosine- } \\
\text { 5)-methyltransferase } \\
\text { (CMT3) }\end{array}$ & 829 & AT1G69770.1 & $\begin{array}{l}\text { DNA (cytosine- } \\
\text { 5)-methyltransferase } \\
\text { CMT3 }\end{array}$ & 52 & 96 & 0.0 \\
\hline FtPinG0009406600.01 & $\begin{array}{l}\text { DNA methyltransferase } \\
\quad(M E T 1)\end{array}$ & 1553 & AT4G08990.1 & $\begin{array}{l}\text { DNA methyltransferase } \\
1\end{array}$ & 56 & 97 & 0.0 \\
\hline FtPinG0006897400.01 & $\begin{array}{l}\text { DNA methyltransferase } \\
\quad(\text { MET2) }\end{array}$ & 1564 & AT5G49160.1 & $\begin{array}{l}\text { DNA methyltransferase } \\
2\end{array}$ & 58 & 95 & 0.0 \\
\hline FtPinG0009482900.01 & $\begin{array}{l}\text { DNA glycosylase } \\
\text { DEMETER }(\text { DME1) }\end{array}$ & 607 & AT5G04560.1 & $\begin{array}{l}\text { DNA glycosylase } \\
\text { DEMETER }\end{array}$ & 69 & 93 & 0.0 \\
\hline FtPinG0007109000.01 & $\begin{array}{l}\text { DNA glycosylase } \\
\text { DEMETER }(D M E 2)\end{array}$ & 1856 & AT5G04560.1 & $\begin{array}{l}\text { DNA glycosylase } \\
\text { DEMETER }\end{array}$ & 66 & 46 & 0.0 \\
\hline FtPinG0003657700.01 & $\begin{array}{l}\text { DNA glycosylase } \\
\text { DEMETER }(D M E 3)\end{array}$ & 1598 & AT5G04560.1 & $\begin{array}{l}\text { DNA glycosylase } \\
\text { DEMETER }\end{array}$ & 46 & 44 & $1 \mathrm{E}-55$ \\
\hline FtPinG0007109000.01 & $\begin{array}{l}\text { DNA glycosylase, } \\
\text { repressor of tran- } \\
\text { scriptional gene } \\
\text { silencing }(\text { ROS } 1)\end{array}$ & 1856 & AT2G36490.1 & $\begin{array}{l}\text { DNA glycosylase, } \\
\text { repressor of tran- } \\
\text { scriptional gene } \\
\text { silencing, ROS1 }\end{array}$ & 46 & 66 & 0.0 \\
\hline
\end{tabular}

demonstrated that the overexpression of these proteins in Arabidopsis led to telomere dysfunction and serious morphological defects. The constant monitoring of the EST1 and cyclin-dependent kinase (CDK) gene expression levels can shed more light on the participation of these genes in the cell cycle, and as a result, on their contribution to the stability/ instability of the MC and NC. Thus, in the future research, it would be interesting to measure the telomere length in the $\mathrm{MC}$ and NC using the terminal restriction fragments. This could help in gaining an understanding of the reason for the high expression level of TERT and FtPotl in the NC.

As was mentioned earlier, the $\mathrm{NC}$ has a very fast growth rate and, as a result, very fast senescence processes compared to the MC. We hypothesise that the ethylene biosynthesis genes are overexpressed in the $F$. tataricum NC. Together with other hormones, ethylene plays a key role in the senescence processes (Iqbal et al. 2017). To compare the level of the gene expression that is connected with the ethylene biosynthesis, we selected the main genes that are connected with this process such as 1-aminocyclopropane-1-carboxylic synthase (ACS2 and ACS6), 1-aminocyclopropane-1-carboxylic acid-oxidase (ACO) and ethylene response factor $(E R F)$. We demonstrated a higher expression of both ACS2 and ACS6 in the NC, and an increase in the $A C O 1$ level in the MC. Such differences in the ACS 2 and $A C S 6$ expression can lead to the overproduction of ethylene and the induction of fast senescence processes in the $\mathrm{NC}$. The higher expression level of the $A C O 1$ in the $\mathrm{MC}$ may 
(a)
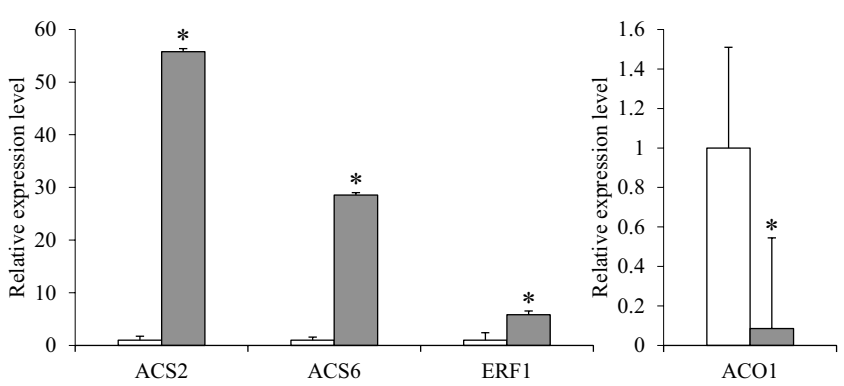

(c)

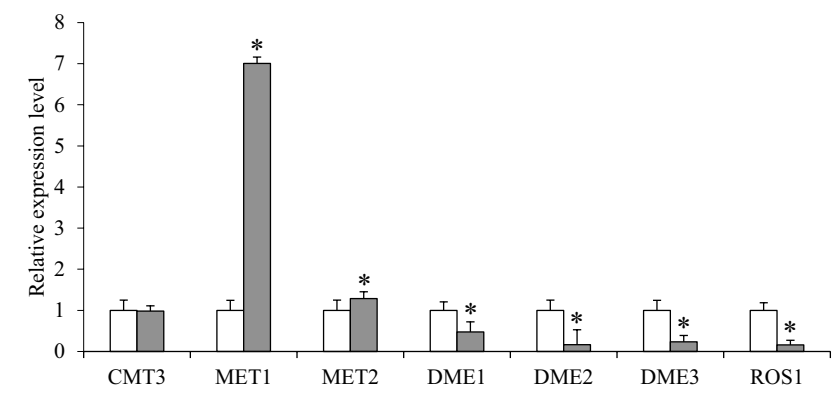

Fig. 6 a Relative expression levels of selected genes connected with ethylene biosynthesis and metabolism of ethylene precursors: ACS2, ACS6, ACO1, ERF1, b relative expression levels of selected genes connected with the telomere maintenance: TERT, EST1, POT1, $P O T 2$, c relative expression levels of selected genes connected with DNA methyltransferases and demethylases in the MC and NC and $\mathbf{d}$

be associated with the PECCs that appeared on the surface of the MC on the 11th day of cultivation. Moreover, in the present study we observed an increase in the ERF1 expression that may be connected with the oxidative stress present in the NC. ERF1 is upregulated during the stress response to abiotic stressors such as water deficit, cold and salt treatment (Lestari et al. 2018; Makhloufi et al. 2014). The ethylene and jasmonate pathways converge in the transcriptional activation of ERF1 in order to prevent the progression of a disease in Arabidopsis (Lorenzo et al. 2003). To summarise, the reaction to the ethylene production or overproduction can differ among the species. It was demonstrated that the addition of ACC, which is an ethylene precursor that promotes ethylene production in the barley genotype Morex, increased the green plant regeneration compared to another genotype, Golden Promise, which had a reduced regeneration after the addition of ACC (Jha et al. 2007). Such differences seem to be connected with higher production of ethylene in Golden Promise than is required to increase the plant regeneration rates. The use of ethylene inhibitors such as aminoethoxyvinylglycine, cobalt chloride and silver thiosulphate in Sinningia speciose and Picea glauca significantly improved the frequency of regeneration (Chae et al. 2012).

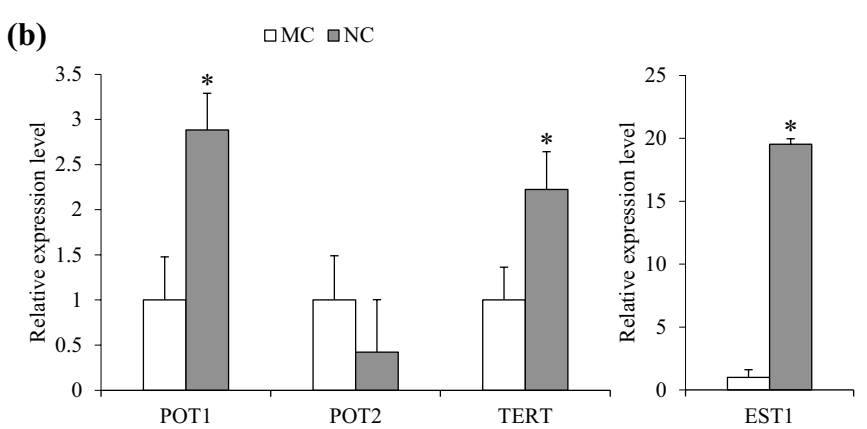

(d)

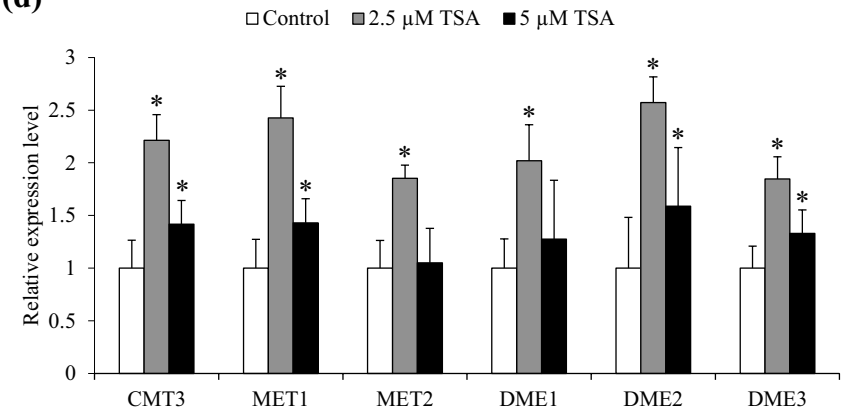

subjected to treatment with 2.5 and $5 \mu \mathrm{M}$ TSA. Relative expression levels were normalised to an internal control (FtPinG0002124000.01, the gene encoding for actin) and calibrated to the control culture (MC cultivated on RX medium). *Value is significantly different from the control culture $(\mathrm{p}<0.05, \mathrm{n}=3 \pm \mathrm{SD})$

There is no information in the literature about the expression of the DNA methyltransferase genes in the genus Fagopyrum. We demonstrated that the expression of DNA methyltransferase is higher in the NC. On the other hand, DNA demethylases had higher expression levels in the MC. Similar results were reported on the transcriptome-based characterisation of a habituated and non-habituated cell culture of Arabidopsis by Pischke et al. (2006). These authors showed the upregulation of METI, CMT1 and CMT3 in habituated calli. In their analyses of the global DNA methylation that had been isolated from embryogenic and non-embryogenic calli of Eleuterococcus senticosus, Chakrabarty et al. (2003) demonstrated a significantly lower level of DNA methylation in the embryogenic calli. It should be noted that ROS1/ DEMETER family gene expression is lower in the NC compared to the MC. It was shown in Arabidopsis that a mutation in the ros 1 gene leads to DNA hypermethylation and enhances transcriptional gene silencing (Agius et al. 2006; Gong et al. 2002). Moreover, the authors stressed that the overexpression of ROS1 in transgenic plants leads to a reduced level of cytosine methylation, and to a higher target gene expression. Tang et al. (2016) showed that ROS1 preferentially targets the transposable elements (TEs) and 
intergenic regions. Thus, ROS1 may prevent the spread of DNA methylation from the TEs to nearby genes.

In order to determine the affect of the HDAC inhibition on the DNA methyltransferases/demethylases, we used TSA, which is known to be effective in inhibiting HDACs by displacing the zinc ion from the active centre of class 1 and 2 of the family of enzymes, including plant HDACs. When optimising doubled haploidy in wheat, Jiang et al. (2017) demonstrated that TSA increases the regeneration of an embryo and green plant. They indicated that using this agent can be useful in the rapid improvement of the wheat germplasm as well as in dealing with in vitro recalcitrance. The experiments on Brassica napus showed that HDACs regulate the switch to the haploid embryogenesis, and that blocking their activity by TSA in cultured male gametophytes leads to an increase in the proportion of that switch from pollen to embryogenic growth ( $\mathrm{Li}$ et al. 2014). In our experiments, we observed an increase in the expression of both DNA methyltransferases and demethylases after the TSA treatment at a concentration of $2.5 \mu \mathrm{M}$.

\section{Conclusion}

In this study, we investigated the stability $v s$ instability processes in the MC and NC of F. tataricum. The immunolocalisation of five antibodies showed differences between diverse types of callus. We found that: (1) the MAC207 antibody seems to be a marker of the MC, which is due to the lack of its signal in the NC, (2) LM2 can be used as a marker of the embryogenically determined cells in the MC, (3) the constant oxidative stress in NC may be connected with the fast senescence process and as a result the upregulation of the genes that are connected with telomere complexity, ethylene biosynthesis and DNA methyltransferases expression and (4) TSA at a concentration of $2.5 \mu \mathrm{M}$ leads to a significant increase in the expression of both DNA methyltransferases and demethylases.

In a future study, the continuous measurement of the ESTI and CDKs expression as well as the telomere length should be considered. The measurements of the ethylene concentration, treatments with inhibitors of HDAC and ethylene biosynthesis should also be considered.

Acknowledgements $\mathrm{AB}$ received a Grant for young scientists from the Faculty of Biology and Environmental Protection, University of Silesia in Katowice. We would like to thank Marta Sowa (Department of Plant Anatomy and Cytology, University of Silesia in Katowice) for her excellent technical assistance in cultivating the plants.

Author contributions Authors' contributionsAB conceived of and designed the study and supervised its execution. $\mathrm{AB}, \mathrm{AMH}$ and $\mathrm{AP}$ carried out the experiments: $\mathrm{AB}$ and $\mathrm{AMH}$ performed immunocytochemistry analyses; AB and AP performed the RT-qPCR experiments. $\mathrm{AB}, \mathrm{EK}, \mathrm{RH}$ drafted the manuscript with contributions from all of the authors. All of the authors read and approved the final manuscript.

\section{Compliance with ethical standards}

Conflict of interest The authors declare that they have no conflict of interest.

Ethical approval The authors declare that the study was carried out according to the accepted professional conduct. However, no ethical approval was needed for the study as it did not involve the use of animals or human subjects.

OpenAccess This article is distributed under the terms of the Creative Commons Attribution 4.0 International License (http://creativeco mmons.org/licenses/by/4.0/), which permits unrestricted use, distribution, and reproduction in any medium, provided you give appropriate credit to the original author(s) and the source, provide a link to the Creative Commons license, and indicate if changes were made.

\section{References}

Agius F, Kapoor A, Zhu JK (2006) Role of the Arabidopsis DNA glycosylase/lyase ROS1 in active DNA demethylation. PNAS 103(31):11796-11801. https://doi.org/10.1073/pnas.0603563103

Akulov AN, Gumerova EA, Rumyantseva N (2018) Cell cultures of Fagopyrum tataricum as a source of biologically active phenolic compounds. In: Zhang M, Kreft I, Suvorova G, Tang Y, Woo SH (eds) Buckwheat germplasm in the world. Elsevier, Cambridge, pp 259-268

Basavaraju P, Shailasree S, Shetty NP, Kini RK, Jorgensen HJL, Neergaard E, Shetty HS (2009) Infection induced oxidative crosslinking of hydroxyproline-rich glycoproteins (HRGPs) is associated with restriction of Colletotrichum sublineolum in sorghum. J Plant Interact 4:3:179-186. https://doi.org/10.1080/1742914080 2527169

Betekhtin A, Rojek M, Milewska-Hendel A, Gawecki R, Karcz J, Kurczynska E, Hasterok R (2016) Spatial distribution of selected chemical cell wall components in the embryogenic callus of Brachypodium distachyon. PLoS ONE 11(11):e0167426. https:// doi.org/10.1371/journal.pone.0167426

Betekhtin A, Rojek M, Jaskowiak J, Milewska-Hendel A, Kwasniewska J, Kostyukova Y, Kurczynska E, Rumyantseva N, Hasterok R (2017) Nuclear genome stability in long-term cultivated callus lines of Fagopyrum tataricum (L.) Gaertn. PLoS ONE. https:// doi.org/10.1371/journal.pone.0173537

Borassi C, Sede AR, Mecchia MA, Salgado Salter JD, Marzol E, Muschietti JP, Estevez JM (2016) An update on cell surface proteins containing extensin-motifs. J Exp Bot 67(2):477-487. https ://doi.org/10.1093/jxb/erv455

Bradley DJ, Wood EA, Larkins AP, Galfre G, Butcher GW, Brewin NJ (1988) Isolation of monoclonal-antibodies reacting with peribacteroid membranes and other components of pea root-nodules containing Rhizobium leguminosarum. Planta 173(2):149-160. https://doi.org/10.1007/Bf00403006

Chae SC, Kim HH, Park SU (2012) Ethylene inhibitors enhance shoot organogenesis of gloxinia (Sinningia speciosa). Sci World J 2012:859381. https://doi.org/10.1100/2012/859381 
Chakrabarty D, Yu KW, Paek KY (2003) Detection of DNA methylation changes during somatic embryogenesis of Siberian ginseng (Eleuterococcus senticosus). Plant Sci 165(1):61-68. https://doi. org/10.1016/S0168-9452(03)00127-4

Chapman A, Blervacq AS, Vasseur J, Hilbert JL (2000) Arabinogalactan-proteins in Cichorium somatic embryogenesis: effect of beta-glucosyl Yariv reagent and epitope localisation during embryo development. Planta 211(3):305-314

Corral-Martinez P, Garcia-Fortea E, Bernard S, Driouich A, SeguiSimarro JM (2016) Ultrastructural immunolocalization of arabinogalactan protein, pectin and hemicellulose epitopes through anther development in Brassica napus. Plant Cell Physiol 57(10):2161-2174. https://doi.org/10.1093/pcp/pcw133

Cosi E, Bettini P, Bindi D, Buiatti M (2007) The use of excised roots from in vitro culture for the determination of superoxide production in plants. Plant Cell Tissue Organ Cult 89:203-209. https:// doi.org/10.1007/s11240-007-9239-y

El-Tantawy AA, Solis MT, Da Costa ML, Coimbra S, Risueno MC, Testillano PS (2013) Arabinogalactan protein profiles and distribution patterns during microspore embryogenesis and pollen development in Brassica napus. Plant Reprod 26(3):231-243. https://doi.org/10.1007/s00497-013-0217-8

Fabian C, Ju YH (2011) A review on rice bran protein: its properties and extraction methods. Crit Rev Food Sci Nutr 51(9):816-827. https://doi.org/10.1080/10408398.2010.482678

Fabjan N, Rode J, Kosir IJ, Wang Z, Zhang Z, Kreft I (2003) Tartary buckwheat (Fagopyrum tataricum Gaertn.) as a source of dietary rutin and quercitrin. J Agric Food Chem 51(22):6452-6455. https ://doi.org/10.1021/jf034543e

Gong Z, Morales-Ruiz T, Ariza RR, Roldan-Arjona T, David L, Zhu JK (2002) ROS1, a repressor of transcriptional gene silencing in Arabidopsis, encodes a DNA glycosylase/lyase. Cell 111(6):803-814

Gong SY, Huang GQ, Sun X, Li P, Zhao LL, Zhang DJ, Li XB (2012) GhAGP31, a cotton non-classical arabinogalactan protein, is involved in response to cold stress during early seedling development. Plant Biol (Stuttg) 14(3):447-457. https://doi.org/10.111 1/j.1438-8677.2011.00518.x

Gupta N, Sharma SK, Rana JC, Chauhan RS (2011) Expression of flavonoid biosynthesis genes vis-a-vis rutin content variation in different growth stages of Fagopyrum species. J Plant Physiol 168(17):2117-2123. https://doi.org/10.1016/j.jplph.2011.06.018

Ikeuchi M, Sugimoto K, Iwase A (2013) Plant callus: mechanisms of induction and repression. Plant Cell 25(9):3159-3173. https://doi. org/10.1105/tpc. 113.116053

Iqbal N, Khan NA, Ferrante A, Trivellini A, Francini A, Khan MIR (2017) Ethylene role in plant growth, development and senescence: interaction with other phytohormones. Front Plant Sci 8:475. https://doi.org/10.3389/fpls.2017.00475

Jha AK, Dahleen LS, Suttle JC (2007) Ethylene influences green plant regeneration from barley callus. Plant Cell Rep 26(3):285-290. https://doi.org/10.1007/s00299-006-0252-0

Jiang F, Ryabova D, Diedhiou J, Hucl P, Randhawa H, Marillia EF, Foroud NA, Eudes F, Kathiria P (2017) Trichostatin A increases embryo and green plant regeneration in wheat. Plant Cell Rep 36(11):1701-1706. https://doi.org/10.1007/s00299-017-2183-3

Kamalova GV, Akulov AN, Rumyantseva NI (2009) Comparison of redox state of cells of tatar buckwheat morphogenic calluses and non-morphogenic calluses obtained from them. Biochemistry 74(6):686-694

Kearse M, Moir R, Wilson A, Stones-Havas S, Cheung M, Sturrock S, Buxton S, Cooper A, Markowitz S, Duran C, Thierer T, Ashton B, Meintjes P, Drummond A (2012) Geneious Basic: an integrated and extendable desktop software platform for the organization and analysis of sequence data. Bioinformatics 28(12):1647-1649. https://doi.org/10.1093/bioinformatics/bts199
Khan K, Shewry PR (2009) Wheat: chemistry and technology, 4th edn. AACC International, St. Paul

Kikuchi A, Satoh S, Nakamura N, Fujii T (1995) Differences in pectic polysaccharides between carrot embryogenic and non-embryogenic calli. Plant Cell Rep 14(5):279-284. https://doi.org/10.1007/ BF00232028

Knox JP (1992) Cell-adhesion, cell-separation and plant morphogenesis. Plant J. https://doi.org/10.1111/j.1365-313X.1992.00137.x

Knox JP, Linstead PJ, Peart J, Cooper C, Roberts K (1991) Developmentally regulated epitopes of cell-surface arabinogalactan proteins and their relation to root-tissue pattern formation. Plant J 1(3):317-326. https://doi.org/10.1046/j.1365-313X.1991.t019-00999.x

Kohorn BD (2001) WAKs; cell wall associated kinases. Curr Opin Cell Biol 13(5):529-533

Kohorn BD (2016) Cell wall-associated kinases and pectin perception. J Exp Bot 67(2):489-494. https://doi.org/10.1093/jxb/ erv467

Konieczny R, Swierczynska J, Czaplicki AZ, Bohdanowicz J (2007) Distribution of pectin and arabinogalactan protein epitopes during organogenesis from androgenic callus of wheat. Plant Cell Rep 26(3):355-363. https://doi.org/10.1007/s00299-006-0222-6

Kreft M (2016) Buckwheat phenolic metabolites in health and disease. Nutr Res Rev 29(1):30-39. https://doi.org/10.1017/S095442241 5000190

Lamport DT, Kieliszewski MJ, Showalter AM (2006) Salt stress upregulates periplasmic arabinogalactan proteins: using salt stress to analyse AGP function. N Phytol 169(3):479-492. https://doi.org /10.1111/j.1469-8137.2005.01591.x

Lestari R, Rio M, Martin F, Leclercq J, Woraathasin N, Roques S, Dessailly F, Clement-Vidal A, Sanier C, Fabre D, Melliti S, Suharsono S, Montoro P (2018) Overexpression of Hevea brasiliensis ethylene response factor HbERF-IXc5 enhances growth and tolerance to abiotic stress and affects laticifer differentiation. Plant Biotechnol J 16(1):322-336. https://doi.org/10.1111/pbi.12774

Leszczuk A, Szczuka E (2018) Arabinogalactan proteins: immunolocalization in the developing ovary of a facultative apomict Fragaria $\times$ ananassa (Duch.). Plant Physiol Biochem 123:24-33. https://doi.org/10.1016/j.plaphy.2017.12.003

Li H, Soriano M, Cordewener J, Muino JM, Riksen T, Fukuoka H, Angenent GC, Boutilier K (2014) The histone deacetylase inhibitor trichostatin a promotes totipotency in the male gametophyte. Plant Cell 26(1):195-209. https://doi.org/10.1105/tpc.113.116491

Livak KJ, Schmittgen TD (2001) Analysis of relative gene expression data using real-time quantitative PCR and the $2(\mathrm{~T})(-$ Delta Delta C) method. Methods 25(4):402-408. https://doi.org/10.1006/ meth.2001.1262

Lorenzo O, Piqueras R, Sanchez-Serrano JJ, Solano R (2003) ETHYLENE RESPONSE FACTOR1 integrates signals from ethylene and jasmonate pathways in plant defense. Plant Cell 15(1):165-178. https://doi.org/10.1105/tpc.007468

Lundblad V, Szostak JW (1989) A mutant with a defect in telomere elongation leads to senescence in yeast. Cell 57(4):633-643

Majewska-Sawka A, Munster A (2003) Cell-wall antigens in mesophyll cells and mesophyll-derived protoplasts of sugar beet: possible implication in protoplast recalcitrance? Plant Cell Rep 21(10):946-954. https://doi.org/10.1007/s00299-003-0612-y

Majewska-Sawka A, Nothnagel EA (2000) The multiple roles of arabinogalactan proteins in plant development. Plant Physiol 122(1):310. https://doi.org/10.1104/pp.122.1.3

Makhloufi E, Yousfi FE, Marande W, Mila I, Hanana M, Berges H, Mzid R, Bouzayen M (2014) Isolation and molecular characterization of ERF1, an ethylene response factor gene from durum wheat (Triticum turgidum L. subsp. durum), potentially involved in salt-stress responses. J Exp Bot 65(22):6359-6371. https://doi. org/10.1093/jxb/eru352 
Mareri L, Romi M, Cai G (2018) Arabinogalactan proteins: actors or spectators during abiotic and biotic stress in plants? Plant Biosyst. https://doi.org/10.1080/11263504.2018.1473525

McCabe PF, Valentine TA, Forsberg LS, Pennell RI (1997) Soluble signals from cells identified at the cell wall establish a developmental pathway in carrot. Plant Cell 9(12):2225-2241. https://doi. org/10.1105/tpc.9.12.2225

Namasivayam P, Skepper JN, Hanke D (2010) Distribution of arabinogalactan protein (AGP) epitopes on the anther-derived embryoid cultures of Brassica napus. Pertanika J Trop Agric Sci 33(2):303-313

Olmos E, Garcia De La Garma J, Gomez-Jimenez MC, FernandezGarcia N (2017) Arabinogalactan proteins are involved in saltadaptation and vesicle trafficking in tobacco BY-2 cell cultures. Front Plant Sci 8:1092. https://doi.org/10.3389/fpls.2017.01092

Pan X, Yang X, Lin G, Zou R, Chen H, Samaj J, Xu C (2011) Ultrastructural changes and the distribution of arabinogalactan proteins during somatic embryogenesis of banana (Musa spp. AAA cv. 'Yueyoukang 1'). Physiol Plant 142(4):372-389. https://doi.org /10.1111/j.1399-3054.2011.01478.x

Pattathil S, Avci U, Baldwin D, Swennes AG, McGill JA, Popper Z, Bootten T, Albert A, Davis RH, Chennareddy C, Dong RH, O'Shea B, Rossi R, Leoff C, Freshour G, Narra R, O'Neil M, York WS, Hahn MG (2010) A comprehensive toolkit of plant cell wall glycan-directed monoclonal antibodies. Plant Physiol 153(2):514-525. https://doi.org/10.1104/pp.109.151985

Pennell R (1998) Cell walls: structures and signals. Curr Opin Plant Biol 1(6):504-510

Pennell RI, Knox JP, Scofield GN, Selvendran RR, Roberts K (1989) A family of abundant plasma-membrane associated glycoproteins related to the arabinogalactan proteins is unique to flowering plants. J Cell Biol 108(5):1967-1977. https://doi.org/10.1083/ jcb.108.5.1967

Pennell RI, Janniche L, Kjellbom P, Scofield GN, Peart JM, Roberts K (1991) Developmental regulation of a plasma-membrane arabinogalactan protein epitope in oilseed rape flowers. Plant Cell 3(12):1317-1326. https://doi.org/10.1105/tpc.3.12.1317

Pfaffl MW, Tichopad A, Prgomet C, Neuvians TP (2004) Determination of stable housekeeping genes, differentially regulated target genes and sample integrity: BestKeeper-Excel-based tool using pair-wise correlations. Biotechnol Lett 26(6):509-515

Pischke MS, Huttlin EL, Hegeman AD, Sussman MR (2006) A transcriptome-based characterization of habituation in plant tissue culture. Plant Physiol 140(4):1255-1278. https://doi.org/10.1104/ pp.105.076059

Potocka I, Godel K, Dobrowolska I, Kurczynska EU (2018) Spatiotemporal localization of selected pectic and arabinogalactan protein epitopes and the ultrastructural characteristics of explant cells that accompany the changes in the cell fate during somatic embryogenesis in Arabidopsis thaliana. Plant Physiol Biochem 127:573-589. https://doi.org/10.1016/j.plaphy.2018.04.032

Prochazkova Schrumpfova P, Schorova S, Fajkus J (2016) Telomere- and telomerase-associated proteins and their functions in the plant cell. Front Plant Sci 7:851. https://doi.org/10.3389/ fpls.2016.00851

Renfrew KB, Song X, Lee JR, Arora A, Shippen DE (2014) POT1a and components of CST engage telomerase and regulate its activity in Arabidopsis. PLoS Genet 10(10):e1004738. https://doi. org/10.1371/journal.pgen.1004738

Rumyantseva NI (2005) Arabinogalactan proteins: involvement in plant growth and morphogenesis. Biochemistry 70(10):1073-1085

Rumyantseva NI, Samaj J, Ensikat HJ, Salnikov VV, Kostyukova YA, Baluska F, Volkmann D (2003) Changes in the extracellular matrix surface network during cyclic reproduction of proembryogenic cell complex in the Fagopyrum tataricum (L.) Gaertn. Dokl Biol Sci 391:375-378

Rumyantseva NI, Akulov AN, Mukhitov AR (2004) Extracellular polymers in callus cultures of Fagopyrum tataricum (L.) Gaertn. with different morphogenic activities: time courses during the culture cycle. Prikl Biokhim Mikrobiol 40(5):571-578

Samaj J, Salaj T, Matusova R, Salaj J, Takac T, Samajova O, Volkmann D (2008) Arabinogalactan-protein epitope Gal4 is differentially regulated and localized in cell lines of hybrid fir (Abies alba $\mathrm{x}$ Abies cephalonica) with different embryogenic and regeneration potential. Plant Cell Rep 27(2):221-229. https://doi. org/10.1007/s00299-007-0429-1

Shakirov EV, Surovtseva YV, Osbun N, Shippen DE (2005) The Arabidopsis Pot 1 and Pot2 proteins function in telomere length homeostasis and chromosome end protection. Mol Cell Biol 25(17):7725-7733. https://doi.org/10.1128/ MCB.25.17.7725-7733.2005

Showalter AM (2001) Arabinogalactan-proteins: structure, expression and function. Cell Mol Life Sci 58(10):1399-1417. https://doi. org/10.1007/PL00000784

Smallwood M, Martin H, Knox JP (1995) An epitope of rice threonine-rich and hydroxyproline-rich glycoprotein is common to cell-wall and hydrophobic plasma-membrane glycoproteins. Planta 196(3):510-522

Smallwood M, Yates EA, Willats WGT, Martin H, Knox JP (1996) Immunochemical comparison of membrane-associated and secreted arabinogalactan-proteins in rice and carrot. Planta 198(3):452-459. https://doi.org/10.1007/Bf00620063

Smertenko A, Bozhkov PV (2014) Somatic embryogenesis: life and death processes during apical-basal patterning. J Exp Bot 65(5):1343-1360. https://doi.org/10.1093/jxb/eru005

Smith LG (2001) Plant cell division: building walls in the right places. Nat Rev Mol Cell Biol 2(1):33-39. https://doi.org/10.1038/35048 050

Suprasanna P, Desai NS, Nishanth G, Ghosh SB, Laxmi N, Bapat VA (2004) Differential gene expression in embryogenic, non-embryogenic and desiccation induced cultures of sugarcane. Sugar Biotechnol 6(4):305-309

Tang K, Lang Z, Zhang H, Zhu JK (2016) The DNA demethylase ROS1 targets genomic regions with distinct chromatin modifications. Nat Plants 2(11):16169. https://doi.org/10.1038/nplan ts.2016.169

Taylor S, Wakem M, Dijkman G, Alsarraj M, Nguyen M (2010) A practical approach to RT-qPCR - publishing data that conform to the MIQE guidelines. Methods 50:S1-S5. https://doi.org/10.1016/j. ymeth.2010.01.005

Verdeil JL, Hocher V, Huert C, Grosdemange F, Escoute J, Ferrieáre N, Nicole M (2001) Ultrastructural changes in coconut calli associated with the acquisition of embryogenic competence. Ann Bot. https://doi.org/10.1006/anbo.2001.1408

Willats WG, McCartney L, Mackie W, Knox JP (2001) Pectin: cell biology and prospects for functional analysis. Plant Mol Biol 47(1-2):9-27

Wiśniewska E, Majewska-Sawka A (2008) The differences in cell wall composition in leaves and regenerating protoplasts of Beta vulgaris and Nicotiana tabacum. Biol Plant 52 https://doi. org/10.1007/s10535-008-0124-2

Yasui Y, Hirakawa H, Ueno M, Matsui K, Katsube-Tanaka T, Yang SJ, Aii J, Sato S, Mori M (2016) Assembly of the draft genome of buckwheat and its applications in identifying agronomically useful genes. DNA Res 23(3):215-224. https://doi.org/10.1093/ dnares/dsw012 
Yates EA, Knox JP (1994) Investigations into the occurrence of plant-cell surface epitopes in exudate gums. Carbohydr Polym 24(4):281-286. https://doi.org/10.1016/0144-8617(94)90072-8

Yates EA, Valdor JF, Haslam SM, Morris HR, Dell A, Mackie W, Knox JP (1996) Characterization of carbohydrate structural features recognized by anti-arabinogalactan-protein monoclonal antibodies. Glycobiology 6(2):131-139. https://doi.org/10.1093/ glycob/6.2.131
Zhou M (2018) Buckwheat germplasm in the world, 1st edn. Elsevier, Cambridge

Publisher's Note Springer Nature remains neutral with regard to jurisdictional claims in published maps and institutional affiliations. 